\title{
Carbon, nitrogen, and phosphorus leaching rates from Spartina alterniflora salt marshes
}

\author{
R. Eugene Turner \\ Department of Oceanography and Coastal Sciences and Coastal Ecology Institute, Louisiana State University, Baton Rouge, \\ Louisiana 70803, USA
}

\begin{abstract}
Annual carbon, nitrogen, and phosphorus leachate rates from live Spartina alterniflora Loisel in a Louisiana (USA) salt marsh were estimated to be 200,14 , and $3 \mathrm{~g} \mathrm{~m}^{-2}$, respectively, and to peak in summer and higher salinities. Leachate losses of $\mathrm{P}, \mathrm{N}$ and $\mathrm{C}$ are equivalent to a turnover of live plant tissues of 10,17 and $49 \mathrm{~d}$, respectively, when submerged, and 148,250 and $721 \mathrm{~d}$, respectively, when unsubmerged. Plant leachate losses during marsh submergence and non-submergence are nearly equal because release rates are $15 \times$ greater during submergence. Nitrogen and carbon concentrations relative to phosphorus are proportionately $4 \times$ higher in leachates than in live plant tissues. The amounts released are high enough to account for measured seasonal changes in the heterotrophic rates of the estuarine plankton community. Leachates appear to be an underappreciated yet significant nutrient and carbon source for salt marsh food webs, and of potential widespread significance for many other estuarine communities.
\end{abstract}

\section{INTRODUCTION}

Salt marshes are characterized by large nutrient storage capacities in tissues and sediments and 'leaky' mineral cycles, which is in strong contrast to planktonic and coral reef communities (Pomeroy 1975). Studies of the loss of salt marsh-derived nutrients and organic materials to estuaries have generally focused on particulate detritus, but nutrients and organics are also released from live aboveground macrophyte tissues (herein called leachates). Total C, N and P measurements of leachate losses from salt marsh plants are reported only for one location in Georgia, USA (Sapelo Island) and there are contradictory conclusions concerning the magnitude and significance of leachates released by the dominant salt marsh plant, Spartina alterniflora Loisel. Pakulski (1986) resolved some of the differences between the estimated carbon release rates of Gallagher et al. (1976) and the higher rates estimated by Turner (1978). Reimold (1972) suggested that $\mathrm{P}$ turnover via Spartina sp. leachates was several times daily, whereas McGovern et al. (1979) estimated the phosphate turnover time to be measured in years, not hours. Released leachates are potentially important for estuarine food webs. Turner
(1978) and Wright \& Coffin (1983) concluded that heterotrophic plankton are efficient consumers of the organics in leachates. Bacterial conversion efficiencies of macrophyte leachates have been shown to be substantially higher than from detrital carbon (e.g. Findlay et al. 1986), so determining the magnitude of leachate rates is of interest when investigating estuarine trophic structure.

In this paper I report on the content and quantity of carbon, nitrogen, and phosphorus leachates from Spartina alterniflora plants growing in a Louisiana and 4 U.S. east coast salt marshes. Leachate concentration data are combined with literature values to estimate the quantity of $\mathrm{C}, \mathrm{N}$, and $\mathrm{P}$ leached from S. alterniflora wetlands during and between flooding cycles.

\section{MATERIALS AND METHODS}

Monthly sampling was from a monotypic Spartina alterniflora (Loisel) stand near Leeville, Louisiana, USA. Additional samples were collected in August 1977 from U.S. east coast salt marshes near Charleston (South Carolina), Wachapreague (Virginia), Darien (Connecticut), and Rye (New Hampshire). Leachates were 
collected in the marsh from live $S$. alterniflora plants by submerging the terminal 6 to $20 \mathrm{~cm}$ of attached green tissues into either artificial or filtered $(0.45 \mu \mathrm{m}$ glass fiber filters) tidal creek water and then monitoring changes in solution chemistry. All leaves were first wiped with a damp cloth and leaf cuticles and then inspected to insure that they were not visibly damaged. This procedure is different from that of Gallagher et al. (1976) and Hopkinson \& Schubauer (1984). Gallagher et al. (1976) pointed out that their test solution was not entirely free of organisms because of not wiping or incomplete wiping, and Hopkinson \& Schubauer (1984) were concerned that epiphytes might be damaged by wiping. I did not determine how much leachate might be consumed by epiphytes wiped off the leaves in this series of experiments. Damaged epiphytes were not considered to significantly add to the leachate pool because of the 30 min pre-soaking period that I used; the first few minutcs of submergence result in high and irregular leachate release rates (Turner 1978), which is probably a consequence of an accumulation of previously released leachate on the plant. The immersion solution from this precoaking period was not sampled. therefore, but replaced with new liquid after $30 \mathrm{~min}$. The immersion solution salinity was always within $5 \%$ of ambient soil water salinity for one set of experiments on each sampling date. Release rates were then determined for periods up to $3 \mathrm{~h}$ by determining changes in chemistry from the beginning to end of the experiment.

Other leaves from a Louisiana marsh were also wiped, pre-soaked for exactly $60 \mathrm{~s}$, and then soaked in new solution for only $60 \mathrm{~s}$, twice daily during daylight, at times when winds kept water off the marsh. Plants were continuously protected from rainfall with a plastic semi-transparent tarp held at $2 \mathrm{~m}$ height. The sides of the tarp were open, but light conditions were not measured. Experiments lasted from 24 to $60 \mathrm{~h}$ and 3 to 10 replicates were done each field trip. A longterm release rate by non-submerged aboveground tissues was estimated from a linear regression of the cumulative leachate losses occurring up to each sampling interval versus time (corrected for the $60 \mathrm{~s}$ immersion). Leaves were harvested at the end of the experiment, dried at $80^{\circ} \mathrm{C}$ for $3 \mathrm{~d}$ and weighed to the nearest $0.005 \mathrm{~g}$.

Samples for organic carbon determinations were sealed within $2 \mathrm{~h}$ of collection and analyzed using a persulfate oxidation method and Oceanographic International carbon analyzer calibrated with both inorganic and glucose standards. Previous experiments resulted in the determination that greater than $95 \%$ of the released organics were small enough to be called dissolved organic matter (Turner 1978). Other samples were frozen to later determine the inorganic (nitrate, nitrite and ammonia) and organic nitrogen content
(Total Kjeldahl digestion) and total and inorganic phosphorus content (acid persulfate method; Strickland \& Parsons 1968).

The C:N and C:P atomic ratios in leachates were calculated by 2 methods: (1) averaging the ratios from each individual experiment, and, (2) determining a linear regression of the changes in element concentration before and after submergence, using data from all experiments. The latter method was preferred since, in the first case, errors from chemical analysis are more serious at the lower limits of technique sensitivity.

The vertical distribution of live plant biomass was estimated using seasonally collected live plants from undisturbed $0.25 \mathrm{~m}^{2}$ quadrats at Leeville, Louisiana. Leaves were allowed to hang loosely to simulate their natural distribution during flooding, and cut into $10 \mathrm{~cm}$ segments. The cumulative percent of biomass of live plants at any height $(\mathrm{cm})$ above the marsh floor is described by the formula:

$$
Y_{z}=\frac{1.4 Z}{0.4 H+Z}
$$

where $Y_{z}=$ cumulative percent of the total biomass $Y$, at any height $Z(\mathrm{~cm})$, up to the total height of the plant community, $H(\mathrm{~cm})$. The live biomass below any height interval was then calculated based on plant height and live biomass values derived from the scientific literature. A linear regression of the predicted and observed values of $Y_{z}$ yielded a coefficient of determination $\left(\mathrm{R}^{2}\right)$ of 0.95 in all cases

I calculated seasonal leachate losses using data on salinity, tidal data (R. Baumann unpubl.), leachate rate, and the amount of biomass submerged.

\section{RESULTS}

Seasonal changes in carbon leaching from submerged plants were lowest in winter and at $0 \%$ salinity (Fig. 1). The average leachate release rates for all data collections are presented in Table 1. The coefficient of variance (CV) for 3 replicate measurements was typically 0.5 . The average seasonal release rate in Louisiana was $334 \mu \mathrm{g} \mathrm{C}$ (g dry wt) ${ }^{-1} \mathrm{~h}^{-1}$ for all data combined ( $\mathrm{CV}=0.69$ ). This average leachate release rate is about the same as measured by Pakulski (1986) but 3 times that measured in the summer by both Hopkinson \& Schubauer (1984) and Gallagher et al (1976) for a Georgia salt marsh. The carbon leachate rates at $30 \%$ were $10 \times$ higher in July compared to December, and $3 \times$ higher than that at $0 \%$. The average of 5 monthly estimates of leachate release rates from non-submerged plant tissues was $7.3 \%$ of the leachate loss rates of carbon from submerged plants. 


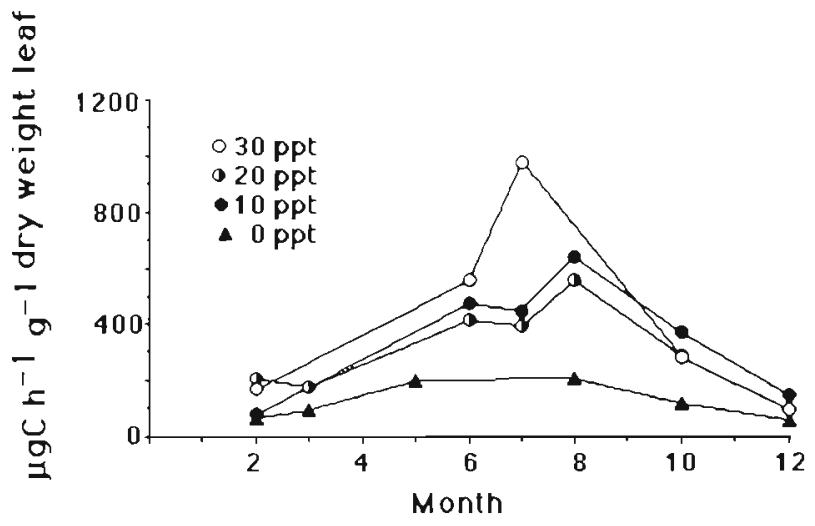

Fig. 1. Spartina alterniflora. Average carbon leachate loss rates at different salinities of soaking solutions from live plants in a Louisiana marsh

More than $85 \%$ of the $\mathrm{C}, \mathrm{N}$, and $\mathrm{P}$ leachates were always in the organic, rather than inorganic forms.

Annual average atomic ratios for leachates from Louisiana salt marshes were calculated to be approximately $16: 1$ for $C: N$ and between $80: 1$ to $164: 1$ for $C$ : $P$ (Table 2). There were no apparent regional differences in the $P: N: C$ ratios determined for the east coast salt marshes during summer. The $P: N: C$ atomic ratio of the leachates averaged $1: 10: 164$ compared to a $\mathrm{P}: \mathrm{N}: \mathrm{C}$ ratio for live plant tissues of $1: 46: 794$ (derived from data in Tables 2 \& 3). Thus, leachates are more enriched with nitrogen and carbon relative to phosphorus compared to concentrations in the live plant. In comparison, Hopkinson \& Schubauer (1984) estimated a $C: N$ ratio of 10.2 for Spartina alterniflora leachates. Turnover times of $\mathrm{C}, \mathrm{N}$ and $\mathrm{P}$ in healthy plant tissues relative to the leachate release rates ranged from 10 to $721 \mathrm{~d}$ (Table 3). The results of McGovern et al. (1979)

Table 1. Average carbon leachate rates $\left(\mu \mathrm{g} \mathrm{C}(\mathrm{g} \text { dry } w \mathrm{t})^{-1} \mathrm{~h}^{-1}\right.$ \pm 1 SD) for this study and for other locations. $N=$ number of sample trips or experimental setups; each trip involved 1 to 3 determinations

\begin{tabular}{|lcc|}
\hline Location & Submerged & Non-submerged \\
\hline $\begin{array}{l}\text { Louisiana, USA } \\
\text { (this study) }\end{array}$ & $\begin{array}{c}334 \pm 249 \\
(\mathrm{~N}=37)\end{array}$ & $\begin{array}{c}24.5 \pm 16.2 \\
(\mathrm{~N}=16)\end{array}$ \\
$\begin{array}{l}\text { Atlantic coast, USA } \\
\quad \text { (this study) }\end{array}$ & $346 \pm 213$ & - \\
$\begin{array}{l}\text { Georgia, USA } \\
\text { (Gallagher et al. 1976) }\end{array}$ & $42-163$ & - \\
$\begin{array}{l}\text { Georgia, USA - summer } \\
\text { (Turner 1978) }\end{array}$ & $200-800$ & $20.6-21.6$ \\
$\begin{array}{l}\text { Georgia, USA - summer } \\
\text { (Hopkinson \& Schubauer } 1984)\end{array}$ & $(\mathrm{N}=33)$ \\
$\begin{array}{l}\text { Georgia, USA } \\
\text { (Pakulski 1986) }\end{array}$ & $16-5 \pm 12.0$ & - \\
\hline
\end{tabular}

Table 2. Average $C: N$ and $C: P$ atomic ratios $( \pm 1$ SD) in leachates from salt marshes. Results from each sampling trip were combined, and the mean atomic ratio determined by (1) average, or (2) linear regression of the concentration of 2 elements in the incubation solution. $N=$ number of sample trips; each trip involved 1 to 3 determinations

\begin{tabular}{|lcc|}
\hline & $\mathrm{C}: \mathrm{N}$ & $\mathrm{C}: \mathrm{P}$ \\
\hline $\begin{array}{l}\text { Louisiana, USA } \\
\text { Average }\end{array}$ & $16.1 \pm 12.1$ & $80.6 \pm 93.9$ \\
$(\mathrm{~N})$ & $(13)$ & $(7)$ \\
Regression & & \\
analysis & 16.2 & 164 \\
$(\mathrm{~N})$ & $(14)$ & $(6)$ \\
Atlantic coast, USA & $8.3 \pm 12.7$ & $465 \pm 320$ \\
$(\mathrm{~N})$ & $(3)$ & $(3)$ \\
\hline
\end{tabular}

and Reimold (1972) are included in Table 3 for comparison and are for phosphate-phosphorus only. The data for $\mathrm{N}$ and $\mathrm{P}$ turnover rates in submerged and nonsubmerged tissues (Louisiana only) are based on the C:N:P atomic ratios summarized in Table 2 and the carbon release rates summarized in Table 1.

The leachate losses during submergence are nearly equal to the losses during the longer periods when plants are not flooded because of the compensatory differences in release rates. Total annual C, N, and P losses as leachates were estimated to be 200,14 , and $3.1 \mathrm{~g} \mathrm{~m}^{-2}$, respectively. The precision and accuracy of these estimates is compromised by the statistical uncertainty in the variability of leachate rates (e.g. the standard deviation for all carbon leachate rates was $69 \%$ of the average), as well as the variability in technique application among investigators.

The seasonal peak in leachate losses of $C, N$ and $P$ was in the summer when biomass is highest.

A crude estimate for leachate losses from a Connecticut marsh during late summer was also obtained by using Steever's (1972) biomass, total plant height and elevation, and tidal data, together with results from Fig. 1 and Tables $1 \& 2$. The estimated annual C, N, and $\mathrm{P}$ losses in Connecticut were 58, 4.2, and $0.9 \mathrm{~g} \mathrm{~m}^{-2}$, respectively. The average annual standing biomass (live plants) in Connecticut is $40 \%$ of that in Louisiana, so it is not surprising that the estimates of leachate losses in Connecticut are $30 \%$ of those in Louisiana.

\section{DISCUSSION}

\section{Carbon}

The total amount of leachate carbon released, $200 \mathrm{~g}$ $\mathrm{C} \mathrm{m}^{-2} \mathrm{yr}^{-1}$, represents from 5 to $10 \%$ of the total net aboveground plant production of Spartina alterniflora 
Table 3. Turnover time (days) of C, N and P as leachates for healthy Spartina alterniflora leaves in various locations in the USA

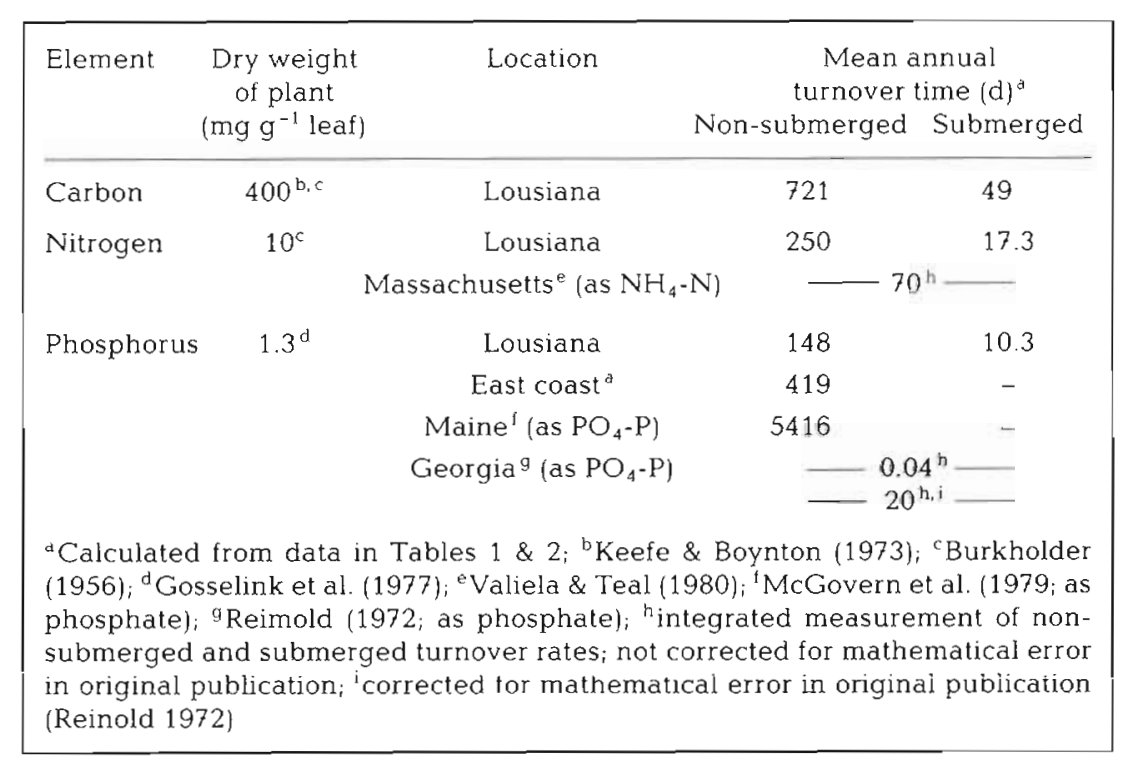

Schubaver (1984) estimated that leachates from a Georgia salt marsh accounted for a total annual flux of $0.7 \mathrm{~g} \mathrm{~m}^{-2}$, or $5 \%$ of that estimated in this study. They assumed a lower leachate loss rate for carbon $\left(102.5 \mu \mathrm{g} \mathrm{C}(\mathrm{g} \text { dry } w t)^{-1} \mathrm{~h}^{-1}\right.$ ), and a $\mathrm{C}: \mathrm{N}$ ratio of 10.2 . They did not measure leachate loss rates of nitrogen when the plant was not flooded and used Gallagher et al.'s (1976) flooding calculations for total flux, which were more conservatively estimated and without the benefit of data on the vertical profiles of plant biomass during flooding. Klopatek (1978) estimated nitrogen leachate losses from a freshwater macrophyte to be $90 \%$ of the particulate losses and equal to a turnover time of $180 \mathrm{~d}$, but his methods were not described. The annual nitrogen leachate release rates for Louisiana, $140 \mathrm{~kg} \mathrm{~N}^{-1}$, are equivalent to estimated nitrogen fixation rates and twothirds the sediment accumulation rate in Louisiana (DeLaune \& Patrick 1980). This leachate release peaks in mid-summer, whereas nitrogen release from dead material is constant throughout the year in Georgia (Gallagher et al. 1980).

\section{Phosphorus}

The results in Table 3 for phosphorus losses are different from those previously published, but these differences may be attributed to technique sensitivity, calculation error, and experimental conditions. For example, Reimold (1972) reported phosphorus leachate rates that were 10000 times higher than those reported by McGovern et al. (1979). Reimold used ${ }^{32} \mathrm{P}$ as a tracer. Data reported since his study suggest that the number of samples may have been inadequate since the specific activity of the isotope may change inside the plant (e.g. Twilley et al. 1977). More importantly, an inadvertent division of the biomass by the dissolved inorganic phosphorus (DIP) concentration, rather than multiplication, occurred in his Table 2 (R. Reimold pers. comm.), so that the product is at least $125 \times$ higher than that which should have appeared regardless of technique. Further, plants were soaked for $4 \mathrm{~h}$, so that the turnover rate given in Reimold's Table 2 is $500 \times$ too high, without correction for technique assumptions. The correct turnover time as phosphate-P should be $20 \mathrm{~d}$ (submerged), not $0.04 \mathrm{~d}$ shown in his Table 2.

Because the summer values are about $2 \times$ the average
There are few comparable measurements of nitrogen released as leachates. Valiela \& Teal (1980) reported a mid-summer leachate loss as ammonia from live leaves of $7 \mathrm{~kg} \mathrm{~d}^{-1}$ for the entire marsh, equivalent to a turnover time of $70 \mathrm{~d}$ for live plant tissue, or $5.6 \mathrm{~g} \mathrm{~N} \mathrm{~m}^{-2} \mathrm{yr}^{-1}$, assuming a growing season of $180 \mathrm{~d}$. If the inorganic nitrogen forms are $10 \%$ of the total leachates and peak in late summer, as in Louisiana, then the total leachate $N$ losses in the Massachusetts marsh are an important component of a marsh $\mathrm{N}$ budget and are similar to data presented in Fig. 1 and Tables 1 \& 2. Hopkinson \& 
annual rate (Fig. 1), and total $\mathrm{P}$ is approximately $10 \times$ the inorganic-P, the appropriate revised number for total $P$ turnover in live submerged plants is about $4 \mathrm{~d}$ for Reimold's (1972) experiments.

In contrast, McGovern et al. (1979) report much lower phosphorus release, but they measured only inorganic phosphorus for unflooded plants. Since total $P$ in the leachates is approximately $10 \times$ the inorganic $P$ released, their data for unflooded plants is also similar to the resuits reported in Table 3.

In comparison, McRoy et al. (1972) measured leaf $\mathrm{P}$ turnover times of $84 \mathrm{~d}$ for submerged eelgrass beds, and Klopatek (1978) measured times of $273 \mathrm{~d}$ for nonsubmerged freshwater macrophytes.

The calculated annual P flux from this Louisiana salt marsh was $3.1 \mathrm{~g} \mathrm{P} \mathrm{m}^{-2}$, which compares to $1.7 \mathrm{~g} \mathrm{P} \mathrm{m}^{-2}$ for a Georgia salt marsh (Pakulski 1992).

\section{CONCLUSIONS}

The patterns in leachate release rates from Spartina alterniflora are similar to those of other plants under comparable conditions. Leachate losses are greatest when the plants are first submerged, then level off to rates that are about $10 \times$ that of nonsubmerged plants (Turner 1978). Marine intertidal halophytes are likely to release DOM since they are wetted regularly, dried often, and commonly must excrete salts. It is not clear. however, whether the leaching of organics is a metabolically active or passive process. Certainly, other wetland plants actually exude organic molecules. These include, for example, proline released during salt stress (Pollak \& Waisel 1970), as well as boron (Pulich 1978), sulphur (Carlson 1980, Pakulski \& Kiene 1992), mercury, cadmium, zinc (Kraus et al. 1986), sodium and potassium. Leaching of inorganic ions from Spartina spp. is also well documented (e.g. Bradley \& Morris 1991, Rozema et al. 1991). Leaching is so common and significant, in fact, that Tukey (1970) wrote in his review of leaching from plants that: 'The extensive list of substances, both organic and inorganic, which can be leached from plants leads one to speculate whether under proper conditions, many, if not all constituents, can be leached.'

Clearly, leachates are utilized by aquatic consumers and epiphytes undoubtedly intercept some leachates before they escape to the water (Penhale \& Smith 1977, Thayer et al. 1978). Salt marsh tidal creek plankton, bacteria and meiofauna readily respire glucose (Hanson \& Snyder 1980, Montagna 1984) and take up these leachates, specifically (Gallagher et al. 1976. Turner 1978). Some marine mussels remove specific free amino acids at $40 \mathrm{nmol} \mathrm{l}^{-1}$ concentration during a single passage of water across the gill (Manahan et al.
1982). Small experimental additions of dissolved organic carbon to stream ecosystems resulted in a disproportionately larger increase in secondary production (Warren et al. 1964) and lake macrophytes are thought to strongly influence in situ oxygen demands via leachate release (Carpenter et al. 1979). Wright \& Coffin (1983) attributed the seasonal accumulation of many large bacteria in 3 northern Massachusetts salt marsh estuaries to increased availability of substrates and suggested dissolved substrates from Spartina alterniflora to be a reasonable substrate source. Findlay et al. (1986) have confirmed the high DOC to bacterial biomass conversion efficiencies (53\%) for aquatic bacteria growing on macrophyte leachates.

Although leachate rates from Spartina alterniflora are low per unit biomass, plant biomass is high (up to $1500 \mathrm{~g}$ dry wt $\mathrm{m}^{-2}$ ) and their impact, therefore, is potentially significant. The leachate flux peaks in the summer and the uptake of these relatively small molecules is rapid, and mediated by organisms larger than $8 \mu \mathrm{m}$ (Turner 1978). Thus, in Georgia salt marsh estuaries the seasonal changes in total plankton heterotrophy (Ragotzkie 1959, Turner 1978) parallel the seasonal changes in macrophyte leachate losses, but not in situ algal production, which is light limited (Turner et al. 1979). The significance of leachate losses relative to in situ production in Louisiana marshes will be somewhat different from Georgia estuaries since turbidity in the former marshes is lower, on average (unpubl. data).

Acknowledgements. I thank R. Reimold, N. Rabalais and W. Kitchens for their reviews and G. Root for the chemical analyses. Two anonymous reviewers and the associate editor provided many helpful comments and Dr D. Pakulski offered timely encouragement. This work was supported by the Louisiana Sea Grant College Program, a part of the National Sea Grant Program, NOAA, U.S. Department of Commerce.

\section{LITERATURE CITED}

Bradley, P. M., Morris, J. T. (1991). Relative importance of ion exclusion, secretion and accumulation in Spartina alterniflora Loisel. J. exp. Bot. 42: 1525-1532

Brylinsky, M. (1977). Release of dissolved organic matter by some marine macrophytes. Mar, Biol. 39: 213-220

Burkholder, P. R. (1956). Studies on the nutritive value of Spartina grass growing in the marsh areas of coastal Georgia. Bull. Torrey Bot. Club 83: 327-334

Carlson, P. R. (1980). Radial oxygen diffusion and the role of Spartina alterniflora in the sulfur cycle of the marsh sediments. Ph.D. thesis, Univ, North Carolina, Chapel Hill

Carpenter, S. R., Gurevitch, A., Adams, M. S. (1979). Factors causing elevated biological oxygen demand in the littoral zone of Lake Wingra, Wisconsin. Hydrobiol. 67: 3-9

DeLaune, R. D., Patrick, W. H. Jr (1980). Nitrogen and phosphorus cycling in a Gulf coast salt marsh. In: Kennedy, V. 
S. (ed.) Estuarine perspectives. Academic Press, New York, p. 143-151

Findlay, S., Carlough, L., Crocker, M. T., Gill, H. K., Meyer J. L., Smith, P. J. (1986). Bacterial growth on macrophyte leachate and fate of bacterial production. Limnol Oceanogr. 31: 1335-1341

Gallagher, J L., Pfeiffer, W. J., Pomeroy, L. R. (1976) Leaching and microbial utilization of dissolved organic carbon from leaves of Spartina alterniflora. Estuar. coast. mar. Sci. $4: 467-471$

Gallagher, J. L., Reimold, R. J., Linthurst, R. A., Pfeiffer, W. J. (1980). Aerial production, mortality, and mineral accumulation-export dynamics in Spartina alterniflora and Juncus roemerianus plant stands in a Georgia salt marsh. Ecology 61: $303-312$

Gosselink, J. G., Hopkinson, C. S. Jr, Parrondo, R. T (1977) Common marsh plant species of the Gulf coast area. Vol. II: Growth dynamics. Tech. Rpt. D-77-44, Dredged Material Research Program, U.S. Army Engineer Waterways Experiment Station, Vicksburg, Miss. 39180

Hanson, R. B., Snyder, J. (1980). Glucose exchanges in a salt marsh-estuary: biological activity and chemical measurements. Limnol. Oceanogr. 25: 633-642

Hopkinson, C. S. Jr, Schubauer, J. P. (1984). Static and dynamic aspects of nitrogen cycling in the salt marsh graminoid Spartina alterniflora. Ecology 65: 961-969

Keefe, C. W., Boynton, W. R. (1973. Standing crop of salt marshes surrounding Cinincuiedyue Bay, MAarylandVirginia. Chesapeake Sci. 14: 117-123

Klopatek, J. M. (1978). Nutrient dynamics of freshwater riverine marshes and the role of emergent macrophytes. In: Goode, R. E., Whigham, D. F., Simpson, R. L., Jackson, C. G. Jr (eds.) Freshwater wetlands: ecological processes and management potential. Academic Press, New York, p. $195-216$

Kraus, M. L., Weis, P., Crow, J. H. (1986). The excretion of heavy metals by the salt marsh cord grass, Spartina alterniflora, and Spartina's role in mercury cycling. Mar. environ. Res. 20: 307-316

Manahan, D. T., Stephens, G. C., Rice, M. A. (1982). Transport of dissolved amino acids by the mussel, Mytilus edulis demonstration of net uptake from natural seawater. Science 215: 1253-1255

McGovern, T. A., Laber, L. J., Gram, B. C. (1979). Characteristics of the salts secreted by Spartina alterniflora Loisel and their relation to estuarine production. Estuar. coast. mar. Sci. 9: 351-356

McRoy, C. P., Barsdate, R. J., Nebert, M. (1972). Phosphorus cycling in an eelgrass (Zostera marina L.) ecosystem. Limnol. Oceanogr. 17: 58-67

Montagna, P. (1984). Competition for dissolved glucose between meiobenthos and sediment microbes. J. exp. mar. Biol. Ecol. 76:177-190

Newell, R. C., Lucas, M. I., Velimirov, B., Seiderer, L. J. (1980). Quantitative significance of dissolved organic losses following fragmentation of kelp (Ecklonia maxima and Laminaria pallida). Mar. Ecol. Prog. Ser. 2: 45-59

Pakulski, J. D. (1986). The release of reducing sugars and dissolved organic carbon from Spartina alterniflora Loisel in a Georgia salt marsh. Estuar. coast. Shelf Sci. 22: 385-394

Pakulski, J. D. (1992). Foliar release of soluble reactive phosphorus from Spartina alterniflora in a Georgia (USA) salt marsh. Mar Ecol. Prog. Ser. 90: 53-60

Pakulski, J. D., Kiene. R. P. (1992). Foliar release of dimethyl- sulfonioproprionate from Spartina alternifora. Mar. Ecol Prog. Ser. 81: 277-287

Penhale, P. A., Smith, W. O. Jr (1977). Excretion of dissolved organic carbon by eelgrass (Zostera marina) and its epiphytes. Limnol. Oceanogr. 22: 400-407

Pollak, G., Waisel, Y (1970). Salt secretion in Aeluropus litoralis (Wildl.) Parl. Ann. Bot. 34:879-888

Pomeroy, L. R. (1975). The strategy of mineral recycling. A. Rev. Ecol. Syst. 1: 171-190

Pulich, W. M. Jr (1978). Photocontrol of boron metabolism in seagrasses. Science 200: 319-320

Ragotzkie, R. A. (1959). Plankton productivity in estuarine waters of Georgia. Publ. Inst. mar. Sci. Univ. Texas 6: 146-158

Reimold, R. J. (1972). The movement of phosphorus through the salt marsh cordgrass, Spartina alterniflora Loisel. Limnol. Oceanogr. 17: 606-611

Rozema, J., Buys, E., Otte, M. L., Broekman, R. A., Ernst, W. H. O. (1991). Ion content and ion excretion of Spartina anglica in relation to salinity and redox potential of salt marsh soil. Z. Pflanzenernähr. Bodenkd. 154 $307-313$

Sieburth, J. McN. (1969). Studies on algal substances in the sea. III. The production of extracellular organic matter by littoral marine algae. J. exp. mar. Biol. Ecol. 3: 290-309

Sieburth, J. McN, Jensen, A. (1969). Studies on algal substances in the sea. I. The formation of Gelbstoff (humic material) by exudates of Phaeophyta. J. exp. mar. Biol. Ecol 3: 275-289

Steever, E. Z. (1972). Productivity and vegetation studies of a tidal salt marsh in Stonington, Connecticut: Cottrell marsh. M. A thesis., Conn. Coll., New London

Strickland, J. D. H., Parsons, T R. (1968). A practical handbook of sea water analysis. Bull. Fish. Res. Bd Can. 167

Thayer, G. W., Parker, P. L., LaCroix, M. W., Fry, B. (1978) The stable isotope ratio of some components of an eelgrass, Zostera marina community. In: Cronin, L. E. (ed.) Recent advances in estuarine research, Vol. 1. Academic Press, New York, p. 518-540

Tukey, H. B. Jr, (1970). The leaching of substances from plants. Ann. Rev. Plant. Physiol. 21. 305-324

Turner, R. E. (1976). Geographic variations in salt marsh macrophyte production: a review. Contr. mar. Sci. 20: 47-68

Turner, R. E. (1978). Community plankton respiration in a salt marsh estuary and the importance of macrophytic leachates. Limnol. Oceanogr. 23: 442-451

Turner, R. E., Woo, S. W., Jitts, H. R. (1979). Phytoplankton production in a turbid, temperate salt marsh estuary Estuar. coast. mar. Sci. 9: 1-11

Twilley, R. R., Brinson, M. M., Davis, G. J. (1977). Phosphorus absorption, translocation, and secretion in Nuphar luteum. Limnol. Oceanogr. 22: 1022-1032

Valiela, I., Teal, J. M. (1980). Inputs, outputs and interconversions of nitrogen in a salt marsh ecosystem. In: Jefferies, R. L., Davy, A. J. (eds.) Ecological processes in coastal environments. Blackwell Sci. Publ., Oxford, p. 399-414

Warren, C. E., Wales, J. H., Davis, G. E., Doudoroff, P. (1964). Trout production in an experimental stream enriched with sucrose. J. Wildl. Mgmt 28: 617-660

Wetzel, R. G., Manny, B. A. (1972). Secretion of dissolved organic carbon and nitrogen by aquatic macrophytes. Verh. int. Ver. Limnol. 18: 162-170

Wright, R. T., Coffin, R. B. (1983). Planktonic bacteria in estuaries and coastal waters of northern Massachusetts: spatial and temporal distribution. Mar. Ecol. Prog. Ser. 11:205-216

Manuscript first received: April 7, 1992

Revised version accepted: October 27, 1992
This article was presented by S. Y. Newell, Sapelo Island, Georgia, USA 